\title{
The Existance of Regional People's Representative Assembly Implementingg Its Fungtions and Roles In The Regional
}

\author{
Tedjo Asmo Sugeng \\ Faculty of Law, University of Abdurachman SalehEast Java, Indonesia \\ Corresponding author: \\ Email: tedjo_asmo_sugeng@unars.ac.id
}

\begin{abstract}
.
This research discusses functions and roles of the Regional People's Representative Assembly (DPR). Type of the research is normative model. The results of this research indicate that the existence of $D P R D$ has not been running optimally, especially for its three functions, namely the function of legislation, budget and supervision. This is due to the lack of understanding of the human resources of DPRD members. It should be based on the principle of "good governance" doing its role as a representative institution, since $D P R D$ positions as a counterbalancing power and exercises effective control over the regional head and all levels of regional government.
\end{abstract}

Keywords: Existence, DPRD, Council Function, Council Role

\section{INTRODUCTION}

Article 18 of the 1945 Constitution and its amendments state the division of Indonesian regions into large and small regions, with the form and structure of government stipulated by law. Anatomically, government affairs are divided into two, namely absolute which is the absolute affairs of the central government (defense, monetary, justice, foreign policy, and religion), and Concurrent (joint affairs with the central, provincial and regency / city). Concurrent government affairs mean government affairs whose handling can be carried out jointly between the central government and regional governments. Thus, any affairs that are concurrent in nature always have a division of affairs that falls under the authority of the central government, there is a division of affairs that is delegated to the province, and there is a division of affairs that is delegated to districts / cities.

The central government has the authority to formulate norms, standards, procedures, monitoring and evaluation of supervision, facilitation and government affairs with national externalities. The provincial government has the authority to regulate and administer government affairs with regional externalities, and regencies / cities have the authority to regulate and manage government affairs with local externalities.

Affairs that fall under regional authority include mandatory and optional affairs. Mandatory government affairs are government affairs related to basic services such as 
basic education, health, fulfillment of minimum living needs, basic environmental infrastructure, while optional government affairs are closely related to superior potential and regional uniqueness. The implementation of regional government is adjusted to the mandate of the 1945 Constitution of the Republic of Indonesia, namely regional government, which regulates and manages government affairs by itself according to the principles of autonomy and co-administration, is directed at accelerating the realization of community welfare through improvement, service, empowerment and community participation, as well as increasing regional competitiveness by taking into account the principles of democracy, equity, justice, privileges and specialties of a region in the system of the Republic of Indonesia. However, in the midst of the implementation of regional autonomy that has been implemented there is a question whether its implementation will run smoothly so that it will have a positive impact on the region or if the implementation of regional autonomy will go awry so that it will actually make the region worse off. In accordance with the applicable laws and regulations from the explanation above, it will appear that the regions are given autonomous rights by the central government to regulate and manage regional interests themselves.

The Republic of Indonesia as a Unitary State adheres to the principle of decentralization in governance by providing opportunities and flexibility for regions to carry out regional autonomy. The purpose of granting autonomy to developmentoriented regions, namely development in a broad sense that includes all aspects of life and livelihood [1]

Regional autonomy is the right, authority and obligation of an autonomous region to regulate and manage government affairs and the interests of the local community in accordance with statutory regulations.

\section{METHODS}

The method used in this research is descriptive analysis method using the normative juridical approach. Descriptive analysis means describing something that becomes the object of research critically through qualitative analysis. Studies, those within the scope of legal science are suitable with the method. It is the normative approach includes: legal principles, synchronization of laws and regulations, including inconcreto legal discovery efforts.

In the context of this research, the approach is made to legal norms contained in several Laws Number 32 of 2004 concerning regional governance and Law Number 33 of 2004 concerning financial balance between central and regional governments.

\section{RESULT AND DISCUSSION}

The implementation of regional autonomy has entered a new era after the government and the DPR agreed to pass Law Number 32 of 2004 concerning Regional Government and Law Number 33 of 2004 concerning Financial Balance between the 
Central and Regional Government. In line with the enactment of the autonomy law, it provides a broader and more responsible running authority for regional government. The balance of duties, functions and roles between the central government and regional governments means that each region must have sufficient income, the region must have adequate sources of financing to assume responsibility for the implementation of regional government.

Implementation of regional governance, the law on Regional Government applies three principles or principles, namely:

1. The principles of decentralization, deconcentration and co-administration;

2. Implementation of the whole and unanimous implementation of the decentralization principle in regencies and municipalities;

3. The principle of co-administration can be implemented in provinces, regencies, cities and villages. [2]

Based on the foregoing, it means that in the implementation of regional government implement three principles, are: (1) decentralization; (2) deconcentration; and (3) coadministration.

Thus it is hoped that each region will be more advanced, independent, prosperous and competitive in the implementation of government and in the development of their respective regions. Indeed, hope and reality will not always go hand in hand. The goal or hope will certainly end well if the implementation and supervision of the implementation also goes well. However, the failure to achieve these expectations appears to be visible in regional autonomy in Indonesia. There are still many problems that accompany the implementation of regional autonomy in Indonesia. These problems certainly have to be resolved so that the initial objectives of regional autonomy can be achieved.

Since the enactment of the Law on Regional Autonomy, many people often talk about its positive aspects. It is undeniable that regional autonomy brings positive changes in the regions in terms of regional authority to regulate themselves. This authority has become a dream because the centralized system of government tends to place regions as actors of development that are not so important or marginal. In the past, the dredging of regional potentials to the center was carried out on the pretext of equitable development. Instead of benefiting from development, the regions have actually experienced an extraordinary process of impoverishment. With this authority, it seems that many regions are optimistic that they will be able to change this unfavorable situation. However, in the midst of this optimism, there is no concern that regional autonomy will also raise several problems which, if not resolved immediately, will complicate regional efforts to advance their people. If the answer is no, it will be very naive. Some unfavorable impacts for the implementation of regional autonomy have occurred. There are had a very bad impact on Indonesia's constitutional structure. These problems include:

a. The existence of exploitation of Regional Income 
b. Unstable understanding of the concepts of decentralization and regional autonomy

c. Inadequate provision of regulations for the implementation of regional autonomy

d. The condition of the human resources of the government apparatus that has not fully supported the implementation of regional autonomy

e. Corruption in the regions

f. The potential for conflict between regions

This problem is a challenge for regional government administrators to prove that regional autonomy can run well with the principles of good governance. What is meant by regional government administrators is regional government. Article 1 point 2 Law Number 32 Year 2004: "The administration of government affairs by the regional government and DPRD according to the principles of autonomy and co-administration with the broadest possible autonomy principle in the system and principles of the Unitary State of the Republic of Indonesia as referred to in the 1945 Constitution." As for the definition of local government (article 1 number 3 Law number 32 of 2004): "Governor, Regent, or Mayor, and regional apparatus as elements of regional government administration."

The Regional People's Representative Assembly (DPRD) is part of the administration of the regional government which also determines the form and outcome of the ongoing regional government. However, the extent to which these functions and roles are carried out will greatly depend on their position when compared with other elements of regional government administration, namely the regional head. This shows, since the reformation the position of DPRD has been strengthened, even at first (based on Law No. 22 of 1999) it has become dominant over the executive. However, in recent developments (Law No. 32 of 2004) the position between the two is directed to be balanced or equal.

The strengthening of the role of the DPRD (Regional People's Representative Council) in the current era of reform and regional autonomy, in which the DPRD's role as a central position is usually reflected in the doctrine of people's sovereignty in this era of regional autonomy, is an interesting phenomenon. The pessimistic responses that previously led to this representative institution are now quite interesting discussions. The shift in the function and role of the legislative body in the era of regional autonomy is marked by the affirmation of the role of the DPRD's duties and authorities, namely in addition to absorbing and channeling people's aspirations into a regional government policy it also carries out a supervisory function. It is more explicitly stated in the general explanation of Law No.32 of 2004, that the DPRD must be integrated with the local community and separated from the regional government.

The purpose of separating the DPRD and the Regional Government is for a control mechanism to occur so that the administration of government in the regions can take place in a healthy manner [3]. For this reason the DPRD is given budget, 
legislative and supervisory functions as well as given very broad rights, duties and authorities according to its position as a regional legislative body.

The demand for ideas made by the community to the government for the implementation of good regional governance is in line with the increase in public knowledge in addition to the globalization of a shift in the paradigm of governance from "rulling government" which continues to move towards "good governance" understood as a democratic phenomenon fairly. For this reason, it is necessary to strengthen the functions and roles of the DPRD so that the executive can carry out their duties properly. However, in reality it is not easy to apply the principles of good governance in a regional government, especially when it is equipped with the problems of regional officials who have their own interests, such as exploitation of regional revenues, corruption and the occurrence of conflicts in the regions. So when the legal system is still fragile and social disorganization occurs on almost all fronts, it is necessary to personalize strong political actors as compensation.

In connection with this principle, there are two orientations that must be considered, the first orientation refers to democratization in state life with constituent elements such as: legitimacy (whether the government is elected and has the trust of its people), accountability scuring of human rights, autonomy, and devolution of power. and assurance of civilian control. Meanwhile, the second orientation depends on the extent to which the government has competence and the extent to which the political and administrative structures and mechanisms function effectively and efficiently.

Good governance is the process of exercising state power in implementing the provision of public good and service called governance (government or governance), while the best practice is called "good governance" (good governance). [4]

The principle of broad autonomy does not mean that it is absolute, or as broad as possible without any boundaries. The most important barrier is the conception of a unitary state, another limitation is the laws and regulations governing the exercise of authority possessed by each autonomous region. Regional autonomy granted to regions is actually more of an obligation than a right. The autonomy that is owned by the regions comes from the central government or the upper level government. Granting this autonomy to the regions of course has a purpose and a goal. In general, the objectives of granting autonomy to regions, according to Sumitro Maskun, are: first, so that regions can organize and manage their own households; second, to increase the effectiveness and effectiveness of government administration; and third, to improve services to the community and the implementation of regional development. Furthermore, Sri Soemantri added that in addition to these three things, the aim of granting autonomy to the regions is an effort to increase people's participation in the regions for their own welfare.

Furthermore, responsible autonomy means that the granting of regional autonomy is truly in line with its objectives, namely to facilitate development in all corners of the country without any conflict between policies given by the central 
government and operational implementation carried out by autonomous recipient regions, so regional development is series of national development as a whole [5]

Bagir Manan has expressed his opinion on broad or broad autonomy as follows: "The broadest possible autonomy is not the transfer of as many government affairs as possible to the regions, but the recognition of regional freedom to take the initiative to regulate and manage government affairs in accordance with the procedures and limitations. determined by law". Based on this opinion, it appears that broad autonomy is emphasized more on the recognition of regions to regulate and manage their own regions. However, when managing his own household it must be based on the aspirations of the local community, not only based on the power and authority possessed by the regional government.

The principles of good governance according to the 1997 UNDP (United Nation Development Program) in suggesting principles that must be adhered to and developed in the practice of good governance, include: [6].

1. Participation

2. Rule of Law

3. Transparency (Transparency)

4. Responsiveness (Responsiveness)

5. Consensus Orientation

6. Equity

7.Effectiveness and Efficiency (Effectiviness and Efficiency)

8. Accountability

9. Strategic Vision

The explanation is as follows:

1. Participation: Every person or community member, both male and female, has the same voting rights in the decision-making process either directly or through representative institutions, in accordance with their respective interests and aspirations.

2. Rule of Law: The legal and statutory framework must be just, upheld and obeyed in its entirety, especially the legal rules regarding human rights.

3. Transparency (Transparency): Transparency must be built in the framework of the free flow of information.

4. Responsiveness: Every institution and its processes must be directed at efforts to serve various interested parties (stakeholders).

5. Consensus Oriented (Consensus Orientation): Good governance will act as an intermediary for different interests to reach a consensus or the best opportunity for the interests of each party, and if possible can also be applied to various policies and procedures to be established by the government.

6. Equity: Good governance will provide both men and women with good opportunities in their efforts to improve and maintain their quality of life. 
7. Effectiveness and Efficiency: Every activity and institutional process is directed to produce something that is really in accordance with the needs through the best possible use of available resources.

8. Accountability: Decision makers in public sector organizations, private and civil society have an accountability to the public (general public), as well as to the owners (stakeholders).

9. Strategic Vision: Leaders and communities have a broad and long-term perspective on good governance and human development, along with a perceived need for development.

The implementation of good governance in the public sector cannot be separated from the vision of a future Indonesia as the focus of the goal of developing good governance. A good government can be said to be a government that respects the sovereignty of the people, has main tasks that include:

1. Protect the entire Indonesian nation and all spilled Indonesian blood,

2. Promote the general welfare,

3. Educate the life of the nation,

4. Implement world order based on freedom, eternal peace and social justice.

The implementation of good governance is a prerequisite for any government to realize people's aspirations and achieve the goals and ideals of a nation as a state. In this context, it is necessary to develop and implement a system of accountability that is precise, clear and legitimate so that governance and development can take place in an efficient, effective, clean and responsible manner, and

\section{CONCLUSION}

The existence of DPRD has not been running optimally, especially for its three functions, namely the function of legislation, budget and supervision. This is due to the lack of understanding of the human resources of DPRD members. It should be based on the principle of "good governance" doing its role as a representative institution, since DPRD positions as a counterbalancing power and exercises effective control over the regional head and all levels of regional government.

\section{REFERENCES}

[1] Kansil dan Kasil Christine, Pemerintahan Daerah Di Indonesia, Sinar Grafika, Jakarta, 2004, hal.9.

[2] Rozali Abdullah, Pelaksanaan Otonomi Luas dan Isu Federalisme Sebagai Suatu Alternatif, Rajawali Press, Jakarta, 2000, hal. 14-15.

[3] J.E Hosio, Kebijakan Publikndan Desentralisasi, Laksbang Yogyakarta, Yogyakarta, 2006, hal.83.

[4] Sedarmayanti, Good Governance Dalam Rangka Otonomi Daerah cetakan pertama, Mandar Maju, Bandung, 2003, hal.2. 
[5] T.B Silalahi, Otonomi Ditinjau Dari Aspek Sumber Daya Manusia” Dimuat dalam Buku Otonomi Daerah Peluang Dan Tantangan, Pustaka Sinar Harapan, Jakarta, 1995, hal. 9.

[6] Bagir Manan, Hubungan Antara Pusat Dan Daerah Menurut UUD 1945, Pustaka Sinar Harapan, Jakarta, 1994, hal. 256. 